\title{
Doğa Sporları Yapanların Temel Psikolojik İhtiyaçlarının Zihinsel Dayanıklılığa Etkisi
}

\author{
The Effects of Basic Psychological Needs of Individuals Doing Outdoor \\ Sports on Mental Toughness
}

\author{
ORİJİNAL ARAȘTIRMA/ \\ ORIGINAL RESEARCH \\ Burak GÜRER ${ }^{1 \dagger}$, \\ Zühal KILINÇ ${ }^{2}$ \\ ${ }^{1}$ Gaziantep Üniversitesi, Beden Eğitimi ve \\ Spor Yüksekokulu, Gaziantep \\ https://orcid.org/0000-0002-0605-3272 \\ ${ }^{2}$ Batman Üniversitesi, Beden Eğitimi ve \\ Spor Yüksekokulu, Batman \\ https://orcid.org/0000-0001-5760-660X
}

\begin{abstract}
Öz
Bu çalışmada, doğa sporları ile uğraşan yapan sporcuların temel psikolojik ihtiyaçlarının zihinsel dayanıklılığına olan etkisinin ortaya konması amaçlanmıştır. Araştırmada, Sheard, Golby ve Van Wersch (2009) tarafindan geliştirilmiş olan ve Türkçe'ye uyarlaması Altıntaş ve Bayar Koruç (2016) tarafindan yapılan sporda "Zihinsel Dayanıklılık Ölçeği” ve doğa sporcularının temel psikolojik ihtiyaçlarını belirlenmek amacıyla Deci ve Ryan (2000) tarafından geliştirilen ve Kesici, Üre, Bozgeyikli ve Sünbül (2003) tarafından Türkçe'ye uyarlanan "Temel Psikolojik İhtiyaçlar” ölçeği kullanılmıştır. Verilerin incelenmesinde Independent samples t testi ve Tek yönlü (One way) Anova testi kullanılmıştır. Sonuçta cinsiyet, yaş ve yapılan doğa sporu türüne göre anlamlı farklara ulaşılmıştır. İstatistiksel olarak deneyimin bir etkisi olmadığı sonucu görülmüştür. Temel psikolojik ihtiyaçlar ile zihinsel dayanıklılık arasında pozitif yönde orta düzeyde bir ilişki tespit edilmiştir. Buna göre, çok güçlü olmasa da temel psikolojik ihtiyaçların karşılaması zihinsel dayanıklılığı olumlu yönde etkilediği söylenebilir. Zihinsel becerileri arttırıcı etkinlikler yaparak psikolojik olarak ihtiyaçların karşılanacağ bir ortamlarda zaman geçirilmesi önerilmektedir.

Anahtar Kelimeler: Doğa Sporu, Psikolojik İhtiyaçlar, Zihinsel Dayanıklılık
\end{abstract}

\section{Yayın Bilgisi}

Gönderi Tarihi: 12.06 .2019

Kabul Tarihi: 02.10.2019

Online Yayın Tarihi: 31.12.2019

DOI:10.33459/cbubesbd.576242

\begin{abstract}
This study intends to examine the impact of the basic psychological needs of athletes doing outdoor sports on their mental toughness. The mental toughness in sports scale developed by Sheard, Golby \& Van Wersch (2009) and adapted to Turkish by Altıntaş and Bayar Koruç (2016) and the Basic Psychological Needs Scale developed by by Deci ve Ryan (2000) and adapted to Turkish by Kesici, Üre, Bozgeyikli and Sünbül (2003) were used. The Independent Samples T test was used to analyze the data obtained as well as the One Way Analysis of Variance (One Way Anova) used in case of the existence of more than two groups and the correlation analysis for the relationship between the two groups. As a result, significant differences were found by the variables gender, age and the type of outdoor sports. It was seen that there was no effect of experience on statistically. A positive correlation was found between basic psychological needs and mental toughness. According to, it can be said that basic psychological needs affect mental toughness say able positively although though weak in strength. It is recommended to spend time in an environment where psychologically needs are met by improving mental skills.
\end{abstract}

Keywords: Outdoor Sports, Psychological Needs, Mental Toughness.

\footnotetext{
†Sorumlu Yazar: burakgurer27@gmail.com.
} 


\section{GíRIŞ}

Morgan ihtiyacı, bireyin fizyolojik ve sonradan kazanılan herhangi bir eksikliği ya da yetmezliği olarak tanımlamaktadır (Morgan, 1984). Bireylerin ihtiyaçları sonsuz ve sınırsızdır. Durum böyle olunca da insanlar sonsuz ve sınırsız ihtiyaçlara göre yeni istek ve taleplerde bulunma ihtiyacında bulunurlar. İhtiyaçları karşılandıkça insanların beklentilerinde ve taleplerinde artışlar görmektedir (Kuzgun, 2000). Bireyler zorunlu fizyolojik ihtiyaçlarını karşıladıkları zaman ihtiyaç hiyerarşilerinin bir devamı olan psikolojik ihtiyaçlarını da karşılamak isterler (Glasser, 1999). William Glasser’a göre, birey ihtiyaçları karşılandığı ölçüde kendisini mutlu ya da mutsuz hissetmektedir. Demek ki, mutluluk ya da mutsuzluk bir kişinin ihtiyaçlarının karşılanma ölçüsünü belirlemek için önemli bir gösterge durumundadır (Akt: Rapport, 2007). Bireyler Öz Belirleme Kuramına göre, bu etkileşim sürecinde desteklenmesi halinde olumlu, engellenmesi halinde ise olumsuz sonuçları olan evrensel nitelikte ve doğuştan gelen özerklik, yeterlik ve ilişki olan üç temel psikolojik ihtiyacı paylaşırlar (Deci ve Ryan, 2000; Deci ve ark., 2001). Kişinin ilişkide özerklik, yeterlilik ve ilişkili olma gibi gereksinimlerini giderebildiğinde karşısındaki kişiye duygusal açıdan daha çok güvendiğini görülmektedir (Deci ve ark., 2000).

Doğada yaşamak ve zaman geçirmek faydalı bir olgudur (Godbey, 2009). Aktiviteler aktif veya pasif yapıldığında, bireylerin uğraş alanı içindeki yaşam biçimini etkileyen çabaları da kapsamakta, insanın toplum içindeki yerlerini korumalarına yardımcı olmakta ve birlikte yaşamı iyi hale getirmektedir (Kelly, 1990). Zihinsel dayanıklılık doğa sporlarında önemli bir etkendir. Hedefe ulaşmada direk bir etkiye sahiptir (Gürer, Karababa ve Canl1, 2019). Zirveye başarılı bir şekilde ulaşabilmek için fiziksel olarak güçlü olmak, gerekli teknik becerilere sahip olmak gerekir (Burke ve Orlick, 2003). Burke ve Orlick (2003) zirve tırmanışında başarılı olamayanlardan kendilerini ayıran farkın; zihinsel olarak güçlü olma, zorluklar sırasında zihinsel stratejiler uygulayabilme yeteneği olduğunu vurgulamıştır. Karakaş, Kaya ve Yılmaz’a (2018) göre, doğada verilen eğitimlerin yaşayarak öğrenme ile birlikte deneyimlenmesi, davranış değişikliklerini beraberinde getirerek öğrenmenin kalıcılığını sağlamaktadır. Doğa sporları ve aktiviteleri gelişmiş ülkelerde sosyal ve ekonomik yaşamın dinamik bir alanıdır. Çünkü bu aktivitelerin birçoğu günümüzde insanların ihtiyaçlarını (doğada olma ihtiyacı, yeni bir deneyim kazanma, macera deneyimi yaşama ve sağlıklı yaşam ve boş zamanlarını etkin bir şekilde geçirme) karşılamaktadır. Yüksek yaşam standartlarının olduğu ve teknolojinin insanların çoğunu etkilendiği ülkelerde, doğa insanların ihtiyaçlarına karşılık vermekte ve doğa sporlarının popülaritesi artmaktadır (Neuman, 2004). Sporcuların fiziksel olarak hazır 
Gürer, B. ve Kılınç, Z. (2019). Doğa sporları yapanların temel psikolojik ihtiyaçlarının zihinsel dayanıklılığa etkisi. CBÜ Beden Eğitimi ve Spor Bilimleri Dergisi, 14 (2), 222-233.

olmalarına rağmen müsabaka veya antrenman performanslarının düşük olması, spor ve egzersiz psikolojisine önem verilme ihtiyacını ortaya çıkarmaktadır. Fiziksel olarak hazır sporcunun beklenen performansı gösterememesi, sporcunun psikolojisi ile açıklanmaya çalışılmaktadır. Yapılan nitel çalışmalarda antrenörlere göre, sporcuların performansının en az \% 50'sini sporcunun zihinsel yapısı sağlamaktadır (Cherry, 2005; Loehr, 1982). Zihinsel dayanıklılık olarak, sporda en üst düzeydeki beklentiler ile ilgili olarak maruz kaldığı baskılara rağmen rakipleriyle daha iyi mücadele etmek için zihinsel açıdan güçlü bir performans sağlayan doğal ya da geliştirilmiş bir psikolojik yapı tanımlaması yapılmaktadır. Özellikle sporcuların rakiplerine göre daha tutarlı, üstün oldukları inancına bağlı olarak kendine güvenen, baskı altında kontrollü davranabilen sporcuların psikolojik bir özelliği olarak tanımlanmaktadır (Connaughton, Wadey, Hanton ve Jones, 2008).

Spor psikolojisi alanında geçmişten günümüze, temel psikolojik ihtiyaçlar ve zihinsel dayanıklılığa yönelik araştırmalar devam etmektedir. Zihinsel olarak iyi olmanın performansı artıracağı düşünülmüştür. Bu çalışmanın amacı, doğa sporları ile uğraşan sporcuların temel psikolojik ihtiyaçlarının zihinsel dayanıklılığına nasıl etki ettiğini ortaya koymaktır.

\section{YÖNTEM}

Araştırmada doğa sporu yapanların temel psikolojik ihtiyaçları ve zihinsel dayanıklılıklarının durumu incelenmeye çalışılmıştır. Metot olarak nicel tekniklerden olan anket uygulama tekniği kullanılmıştır. Demografik özellikler için kişisel bilgi formu, temel psikolojik ihtiyaçlar ölçeği ve zihinsel dayanıklılık ölçeği ile araştırma tasarlanmıştır.

\section{Evren ve Örneklem}

Araştırmanın evrenini, Türkiye'de doğa sporları ile uğraşan sporcular, örneklemi ise araştırmacının ulaşabildiği Adıyaman, Aydın, Çanakkale, Muğla, Antalya, Kocaeli, Osmaniye, Gaziantep, Kocaeli, Kayseri şehirlerindeki rastgele örneklem yöntemi ile seçilmiş sporcular oluşturmuştur. Araştırmaya dağcılık (\% 38,6), binicilik (\% 8,7), doğa yürüyüşü (\% 17), yamaç paraşütü $(\% 7,6)$, dağ bisikleti $(\% 9,8)$, su sporları $(\%$ 8,7) ve kaya tırmanışı $(\%$ 8.3) toplamda 264 (168 erkek, 96 kadın) sporcu katılmıştır.

\section{Veri Toplama Araçları}

Araştırmada, doğa sporcularının zihinsel dayanıklılıklarını incelemek için Sheard, Golby ve Van Wersch (2009) tarafından geliştirilmiş olan ve Türkçe'ye uyarlaması Altıntaş ve 
Bayar Koruç (2016) tarafından yapılan sporda “Zihinsel Dayanıklılık Ölçeği” ve doğa sporcularının temel psikolojik ihtiyaçlarını belirlenmek için Deci ve Ryan (2000) tarafından geliştirilen Kesici, Üre, Bozgeyikli ve Sünbül (2003) tarafından Türkçe’ye uyarlanan “Temel Psikolojik İhtiyaçlar” ölçeği kullanılmıştır.

Deci ve Ryan (2000) tarafından geliştirilen Temel Psikolojik İhtiyaçlar Ölçeğini Kesici ve ark., (2003) Türkçe’ye uyarlanmıştır. Kişinin esas olan psikolojik ihtiyaçlarını belirlemek için Türkçe'ye uyarlanmış ölçeğin orijinalinde 21 ifade bulunmaktadır. Bu ifadeler; Çok doğru: 5, Doğru: 4, Biraz Doğru: 3,Doğru Değil: 2, Hiç Doğru Değil: 1 şeklinde puanlanmıştır. Bu ölçek 3 alt boyuttan meydana gelmektedir. Bireyin alt boyutlardaki maddelerden aldığı puanlar toplanıp, her kişi için 3 alt boyutta ölçek puanı elde edilmektedir. Bu boyutlar; Özerklik İhtiyacı, Yeterlik İhtiyacı ve İlişki İhtiyaçlarıdır (Deci ve Ryan, 2000). Ölçekteki toplam puan en yükssek 35, en düşük 7'dir. Puan yükseldikçe kişi daha fazla psikolojik ihtiyacının karşılandığını hissetmekte, düştükçe psikolojik ihtiyacının karşılanmadığını hissetmektedir. Yeterlik ihtiyacı alt boyutunda toplam puan en yüksek 30, en düşük 6', ilişki ihtiyacında en yüksek 40, en düşük 8'dir. Alt boyutlar aşağıdaki sorulardan oluşmaktadır.

Özerklik ihtiyacı: 1, 4, 8, 11, 14, 17, 20.

Yeterlik ihtiyac1: 3, 5, 10, 13, 15, 19.

İlişki ihtiyacı: 2, 6, 7, 9, 12, 16, 18, 21. maddelerden oluşmaktadır. Araştırmada Temel Psikolojik İhtiyaçlar Ölçeği için Cronbach’s Alpha $(\alpha)$ değeri ,73 olarak bulunmuştur.

Sporda zihinsel dayanıklılık ölçeği 3 alt boyuttan oluşmuştur. Bunlar güven, kontrol ve devamlılık alt boyutlarıdır. "Güven”, mücadele gerektiren zor durumlarda hedefe ulaşmak için yeteneklere inanmayı ve rakiplerden daha iyi olduğunu düşünmeyi ifade etmektedir. "Kontrol”, baskı altında veya beklenmedik durumlar karşısında soğukkanlılığı koruma, kontrollü ve rahat olma kavramlarını içerirken, "Devamlılık”, belirlenen hedefler doğrultusunda sorumluluk alma, konsantre olma ve mücadele etme anlamı taşımaktadır (Sheard, 2013). Güven alt boyutu; 1, 5, 6, 11, 13, 14 nolu maddelerden, Devamlılik alt boyutu; 3, 8, 10, 12 nolu maddelerden ve Kontrol alt boyutu; 2, 4, 7, 9 nolu maddelerden oluşmaktadır (Sheard ve ark., 2009). Araştırmada Sporda Zihinsel Dayanıklılık Ölçeği için Cronbach's Alpha $(\alpha)$ değeri ,70 olarak bulunmuştur. 


\section{Verilerin Analizi}

Araştırmada toplanan veriler SPSS 22.0 paket programı ile analiz edilmiştir. Aritmetik ortalama, frekans, standart sapma gibi tanımlayıcı istatistiklere bakılmıştır. Verilerin dăğlımı için basıklık ve çarpıklık değerlerine bakılmış ve verilerin normal dağglım gösterdiği görülmüştür. Verilerin analizinde Bağımsız Örneklem t testi ve Tek yönlü (One way) Anova testi kullanılmıştır. Temel psikolojik ihtiyaçlar ile zihinsel dayanıklılık arasındaki ilişkiyi ölçmek için ise korelasyon analizi yapılmıştır.

\section{BULGULAR}

Tablo 1: Cinsiyete göre temel psikolojik ihtiyaçlar ve zihinsel dayanıklılık değerleri

\begin{tabular}{|c|c|c|c|c|c|c|c|}
\hline & & Cinsiyet & $\mathbf{N}$ & Ort. & SS & $\mathbf{t}$ & $\mathbf{p}$ \\
\hline \multirow{3}{*}{$\begin{array}{l}\text { Temel } \\
\text { Psikolojik } \\
\text { İhtiyaçlar }\end{array}$} & Özerklik İhtiyacı & $\begin{array}{l}\text { Erkek } \\
\text { Kadın }\end{array}$ & $\begin{array}{r}168 \\
96\end{array}$ & $\begin{array}{l}3,2543 \\
3,1592\end{array}$ & $\begin{array}{l}, 45805 \\
43076\end{array}$ & 1,657 & ,099 \\
\hline & Yeterlik İhtiyacı & $\begin{array}{l}\text { Erkek } \\
\text { Kadın }\end{array}$ & $\begin{array}{r}168 \\
96 \\
\end{array}$ & $\begin{array}{l}3,4286 \\
3,4010 \\
\end{array}$ & $\begin{array}{l}, 45655 \\
, 40723 \\
\end{array}$ & ,490 & ,625 \\
\hline & İlişki İhtiyacı & $\begin{array}{l}\text { Erkek } \\
\text { Kadın }\end{array}$ & $\begin{array}{r}168 \\
96\end{array}$ & $\begin{array}{l}3,3051 \\
3,2799\end{array}$ & $\begin{array}{l}, 37280 \\
, 32984\end{array}$ &, 549 &, 584 \\
\hline \multirow{4}{*}{$\begin{array}{l}\text { Zihinsel } \\
\text { Dayanıklılık }\end{array}$} & Güven & $\begin{array}{l}\text { Erkek } \\
\text { Kadın }\end{array}$ & $\begin{array}{r}168 \\
96\end{array}$ & $\begin{array}{l}3,0942 \\
2,8837\end{array}$ & $\begin{array}{l}, 47269 \\
42517\end{array}$ & 3,609 &, 000 \\
\hline & Devamlılık & $\begin{array}{l}\text { Erkek } \\
\text { Kadın }\end{array}$ & $\begin{array}{r}168 \\
96\end{array}$ & $\begin{array}{l}3,4658 \\
3,4453\end{array}$ & $\begin{array}{l}56529 \\
, 54917\end{array}$ & ,286 &, 775 \\
\hline & Kontrol & $\begin{array}{l}\text { Erkek } \\
\text { Kadın }\end{array}$ & $\begin{array}{r}168 \\
96 \\
\end{array}$ & $\begin{array}{l}2,5893 \\
2,6172 \\
\end{array}$ & $\begin{array}{l}, 61010 \\
, 59929 \\
\end{array}$ &,- 360 & ,719 \\
\hline & $\begin{array}{l}\text { Toplam Zihinsel } \\
\text { Dayanıklılık }\end{array}$ & $\begin{array}{l}\text { Erkek } \\
\text { Kadın }\end{array}$ & $\begin{array}{r}168 \\
96\end{array}$ & $\begin{array}{l}2,8112 \\
2,7381\end{array}$ & $\begin{array}{l}, 27002 \\
, 26335 \\
\end{array}$ & 2,136 & ,034 \\
\hline
\end{tabular}

$\mathrm{P}<, 01 ; \mathrm{p}<, 05$

Cinsiyete göre temel psikolojik ihtiyaçlarda istatistiksel olarak bir fark bulunamamıştır. Zihinsel dayanıklılıkta ise güven alt boyutunda ve toplam puanda anlamlı farklara rastlanmıştır. Zihinsel dayanıklılıkta sonuçlar erkekler lehinedir. "Güven", mücadele gerektiren zor durumlarda hedefe ulaşmak için yeteneklere inanmayı ve rakiplerden daha iyi olduğunu düşünmeyi ifade etmektedir (Sheard, 2013). Erkekler zihinsel olarak kadınlardan daha dayanıklı olduğu söylenebilir. 
Gürer, B. ve Kılınç, Z. (2019). Doğa sporları yapanların temel psikolojik ihtiyaçlarının zihinsel dayanıklılığa etkisi. CBÜ Beden Eğitimi ve Spor Bilimleri Dergisi, 14 (2), 222-233.

Tablo 2: Yaşa göre temel psikolojik ihtiyaçlar ve zihinsel dayanıklılık değerleri

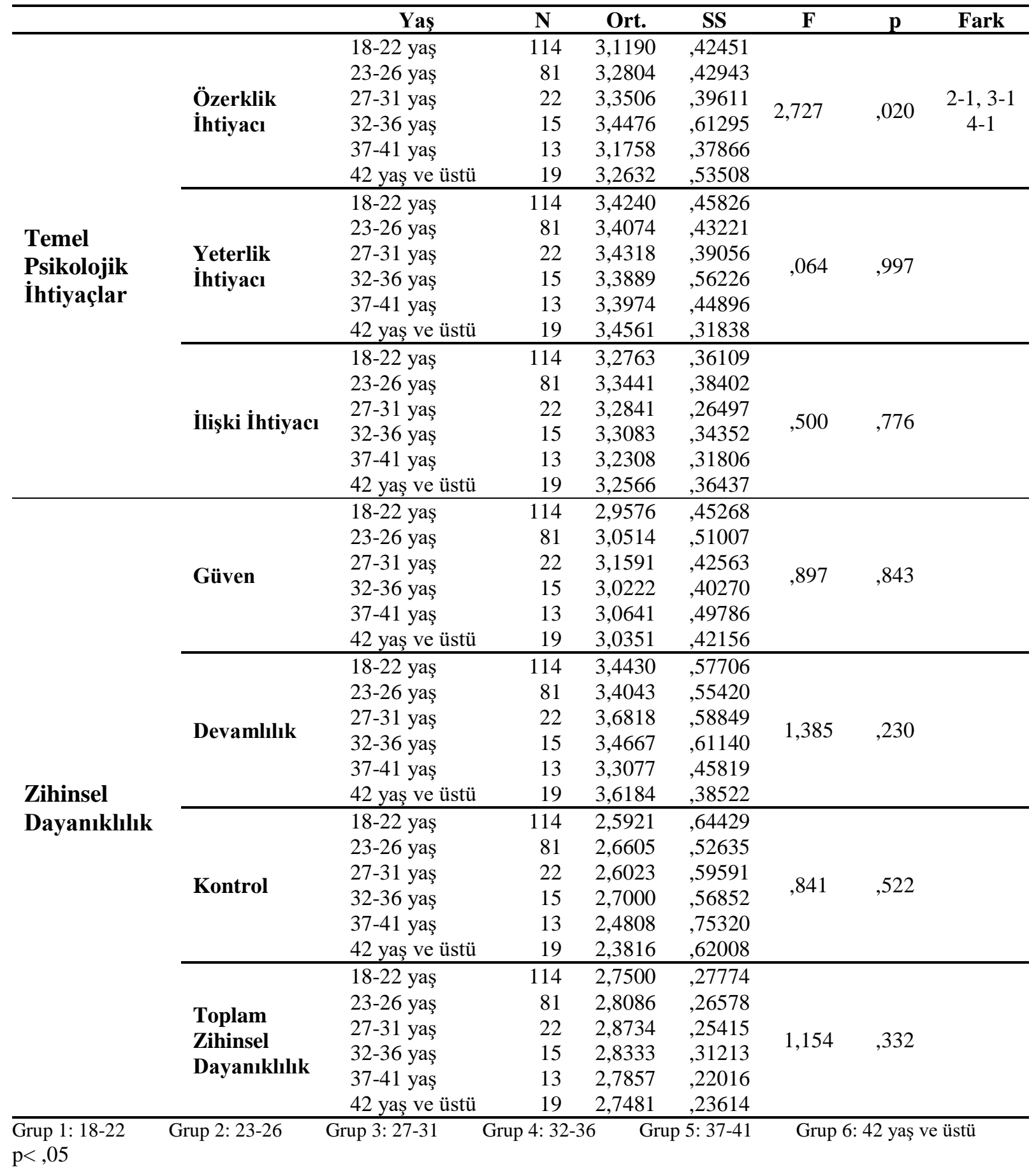

Temel psikolojik ihtiyaçların alt boyutu olan özerklik ihtiyacında anlamlı farklar bulunmuştur. 32-36 yaş aralığındaki sporcular daha fazla özerklik ihtiyacı hissetmektedir. 
Gürer, B. ve Kılınç, Z. (2019). Doğa sporları yapanların temel psikolojik ihtiyaçlarının zihinsel dayanıklılığa etkisi. CBÜ Beden Eğitimi ve Spor Bilimleri Dergisi, 14 (2), 222-233.

Tablo 3: Doğa sporu türüne göre temel psikolojik ihtiyaçlar ve zihinsel dayanıklılık değerleri

\begin{tabular}{|c|c|c|c|c|c|c|c|c|}
\hline & & Spor Çeşidi & $\mathbf{N}$ & Ort. & SS & $\mathbf{F}$ & $\mathbf{p}$ & Fark \\
\hline \multirow{21}{*}{$\begin{array}{l}\text { Temel } \\
\text { Psikolojik } \\
\text { İhtiyaçlar }\end{array}$} & \multirow{7}{*}{$\begin{array}{l}\text { Özerklik } \\
\text { İhtiyacı }\end{array}$} & Dağcılik & 102 & 3,2143 & ,43010 & \multirow{7}{*}{,885 } & \multirow{7}{*}{, 506} & \\
\hline & & Binicilik & 23 & 3,3602 & 48707 & & & \\
\hline & & Yamaç Paraşütü & 20 & 3,1643 & ,46413 & & & \\
\hline & & Doğa Yürüyüşü & 45 & 3,2603 & ,43104 & & & \\
\hline & & Dağ Bisikleti & 26 & 3,2198 & 49028 & & & \\
\hline & & Su Sporları & 23 & 3,0745 & 45354 & & & \\
\hline & & Kaya Tırmanışı & 25 & 3,2171 & ,47581 & & & \\
\hline & \multirow{7}{*}{$\begin{array}{l}\text { Yeterlik } \\
\text { İhtiyacı }\end{array}$} & Dağcclik & 102 & 3,4330 & ,43956 & \multirow{7}{*}{1,019} & \multirow{7}{*}{,414 } & \\
\hline & & Binicilik & 23 & 3,3333 & 46330 & & & \\
\hline & & Yamac Parașütü & 20 & 3,3917 & 46288 & & & \\
\hline & & Doğa Yürüyüşü & 45 & 3,5111 & 38501 & & & \\
\hline & & Dağ Bisikleti & 26 & 3,4423 & ,40809 & & & \\
\hline & & Su Sporları & 23 & 3,2609 & ,57697 & & & \\
\hline & & Kaya Tırmanış1 & 25 & 3,4133 &, 36043 & & & \\
\hline & \multirow{7}{*}{ İlişki İhtiyacı } & Dağccllık & 102 & 3,2904 & ,31865 & \multirow{7}{*}{,460 } & \multirow{7}{*}{,837 } & \\
\hline & & Binicilik & 23 & 3,3370 & ,49634 & & & \\
\hline & & Yamaç Paraşütü & 20 & 3,2875 & ,40372 & & & \\
\hline & & Doğa Yürüyüşü & 45 & 3,3083 &, 36307 & & & \\
\hline & & Dağ Bisikleti & 26 & 3,3702 & ,34907 & & & \\
\hline & & Su Sporlar1 & 23 & 3,2554 & ,36827 & & & \\
\hline & & Kaya Tırmanışı & 25 & 3,2250 & ,33072 & & & \\
\hline \multirow{28}{*}{$\begin{array}{l}\text { Zihinsel } \\
\text { Dayanıklılık }\end{array}$} & \multirow{7}{*}{ Güven } & Dağcilık & 102 & 3,0016 & ,45082 & \multirow{7}{*}{,738 } & \multirow{7}{*}{,619 } & \\
\hline & & Binicilik & 23 & 2,9130 & ,35487 & & & \\
\hline & & Yamaç Paraşütü & 20 & 3,0750 & ,55270 & & & \\
\hline & & Doğa Yürüyüşü & 45 & 3,0000 & ,45505 & & & \\
\hline & & Dağ Bisikleti & 26 & 3,1346 & ,43721 & & & \\
\hline & & Su Sporları & 23 & 2,9565 & 61999 & & & \\
\hline & & Kaya Tırmanışı & 25 & 3,1000 & ,44618 & & & \\
\hline & \multirow{7}{*}{ Devamlılık } & Dağccllık & 102 & 3,4828 & ,54302 & \multirow{7}{*}{1,029} & \multirow{7}{*}{,406 } & \\
\hline & & Binicilik & 23 & 3,4565 & ,52034 & & & \\
\hline & & Yamaç Paraşütü & 20 & 3,3750 & 63089 & & & \\
\hline & & Doğa Yürüyüşü & 45 & 3,5500 & ,54512 & & & \\
\hline & & Dağ Bisikleti & 26 & 3,4615 & 61111 & & & \\
\hline & & Su Sporlar1 & 23 & 3,2174 & 64095 & & & \\
\hline & & Kaya Tırmanış1 & 25 & 3,4800 &, 47280 & & & \\
\hline & \multirow{7}{*}{ Kontrol } & Dağc1lık & 102 & 2,4681 & 60798 & \multirow{7}{*}{3,284} & \multirow{7}{*}{,004 } & \\
\hline & & Binicilik & 23 & 2,9348 & ,59457 & & & \\
\hline & & Yamaç Paraşütü & 20 & 2,6250 & ,43301 & & & $2-1,5-1$ \\
\hline & & Doğa Yürüyüşü & 45 & 2,5444 & ,61766 & & & $6-1,2-4$ \\
\hline & & Dağ Bisikleti & 26 & 2,8269 & ,58638 & & & $2-7$ \\
\hline & & Su Sporlar1 & 23 & 2,7826 & 65411 & & & \\
\hline & & Kaya Tırmanışı & 25 & 2,5000 &, 50000 & & & \\
\hline & & Dağc1lık & 102 & 2,7213 & ,24384 & & & \\
\hline & & Binicilik & 23 & 2,8758 & ,28426 & & & \\
\hline & Toplam & Yamaç Paraşütü & 20 & 2,8179 & 23345 & & & \\
\hline & Zihinsel & Doğa Yürüyüşü & 45 & 2,7667 & 26787 & 2,783 & 012 & $2-1,2-5$ \\
\hline & Dayanıklılık & Dağ Bisikleti & 26 & 2,9121 & ,24185 & & & 2-6 \\
\hline & & Su Sporları & 23 & 2,8509 & ,35903 & & & \\
\hline & & Kaya Tırmanış1 & 25 & 2,7714 & ,26245 & & & \\
\hline
\end{tabular}

p<,05 Grup 1: Dağcılık Grup 2:Binicilik Grup 3: Yamaç paraşütü

Grup 5: Dağ Bisikleti Grup 6: Su Sporları Grup 7: Kaya tırmanış1

Doğa sporu türüne, zihinsel dayanıklılık alt boyutu olan kontrolde anlamlı farka rastlanmıştır. Buna göre binicilik sporu yapanlar çok daha kontrollü olmakla birlikte dağcılık sporu yapanların kontrolünün daha zayıf olduğu görülmüştür. "Kontrol”, baskı altında veya beklenmedik durumlar karşısında soğukkanlılı̆̆ koruma, kontrollü ve rahat olma gibi 
Gürer, B. ve Kılınç, Z. (2019). Doğa sporları yapanların temel psikolojik ihtiyaçlarının zihinsel dayanıklılığa etkisi. CBÜ Beden Eğitimi ve Spor Bilimleri Dergisi, 14 (2), 222-233.

kavramları içermektedir (Sheard, 2013). Genel zihinsel dayanıklılık puanlarında ise dağ bisikleti yapanlar lehine sonuç ortaya çıkmıştır.

Tablo 4: Deneyime göre temel psikolojik ihtiyaçlar ve zihinsel dayanıklılık değerleri

\begin{tabular}{|c|c|c|c|c|c|c|c|}
\hline & & Deneyim & $\mathbf{N}$ & Ort. & SS & $\mathbf{F}$ & $\mathbf{p}$ \\
\hline \multirow{12}{*}{$\begin{array}{l}\text { Temel } \\
\text { Psikolojik } \\
\text { İhtiyaçlar }\end{array}$} & & $1-3$ y1l & 181 & 3,2123 & ,43789 & \multirow{4}{*}{,640 } & \multirow{4}{*}{,590 } \\
\hline & Özerklik & $4-7$ y1l & 55 & 3,2286 & ,46786 & & \\
\hline & \multirow[t]{2}{*}{ İhtiyacı } & $8-11$ y1l & 18 & 3,1667 & ,49061 & & \\
\hline & & 12 y1l ve üstü & 10 & 3,4000 & ,51640 & & \\
\hline & & $1-3$ y1l & 181 & 3,4217 & ,42511 & \multirow{4}{*}{1,386} & \multirow{4}{*}{,247 } \\
\hline & Yeterlik & 4-7 yil & 55 & 3,4333 & , 45088 & & \\
\hline & \multirow{2}{*}{ İhtiyacı } & 8-11 y1l & 18 & 3,2500 & ,58088 & & \\
\hline & & 12 y1l ve üstü & 10 & 3,5833 & 25154 & & \\
\hline & \multirow{4}{*}{ İlişki İhtiyacı } & $1-3$ y1l & 181 & 3,3052 & ,36807 & \multirow{4}{*}{1,039} & \multirow{4}{*}{,376 } \\
\hline & & 4-7 y1l & 55 & 3,3182 & ,31533 & & \\
\hline & & $8-11$ y1l & 18 & 3,1597 & 38779 & & \\
\hline & & 12 yıl ve üstü & 10 & 3,2500 & ,31180 & & \\
\hline \multirow{16}{*}{$\begin{array}{l}\text { Zihinsel } \\
\text { Dayanıklılık }\end{array}$} & \multirow{4}{*}{ Güven } & 1-3 y1l & 181 & 3,0046 & , 45827 & \multirow{4}{*}{,612 } & \multirow{4}{*}{,607 } \\
\hline & & 4-7 yil & 55 & 3,0545 & 40579 & & \\
\hline & & $8-11$ yil & 18 & 2,9537 & 66864 & & \\
\hline & & 12 y1l ve üstü & 10 & 3,1667 & ,52705 & & \\
\hline & \multirow{4}{*}{ Devamlılık } & $1-3$ yil & 181 & 3,4765 & ,54563 & \multirow{4}{*}{1,241} & \multirow{4}{*}{,295 } \\
\hline & & 4-7 yil & 55 & 3,4455 &, 51973 & & \\
\hline & & $8-11$ y1l & 18 & 3,2361 & ,82012 & & \\
\hline & & 12 y1l ve üstü & 10 & 3,6000 & ,37639 & & \\
\hline & \multirow{4}{*}{ Kontrol } & $1-3$ y1l & 181 & 2,6423 & ,57566 & \multirow{4}{*}{1,143} & \multirow{4}{*}{,332 } \\
\hline & & 4-7 y1l & 55 & 2,5273 & ,65205 & & \\
\hline & & $8-11$ y1l & 18 & 2,5139 &, 71472 & & \\
\hline & & 12 yıl ve üstü & 10 & 2,3750 & ,64818 & & \\
\hline & \multirow{4}{*}{$\begin{array}{l}\text { Toplam } \\
\text { Zihinsel } \\
\text { Dayanıklılık }\end{array}$} & 11-3 y1l & 181 & 2,7861 & ,28646 & \multirow{4}{*}{,269 } & \multirow{4}{*}{,848 } \\
\hline & & 4-7 y1l & 55 & 2,7870 & ,23630 & & \\
\hline & & $8-11$ y1l & 18 & 2,7381 & 24377 & & \\
\hline & & 12 yıl ve üstü & 10 & 2,8286 &, 16218 & & \\
\hline
\end{tabular}

Tablo 5: Sporcuların temel psikolojik ihtiyaçlar ve zihinsel dayanıklılık korelasyon analizi

\begin{tabular}{lcc}
\hline & Temel Psikolojik İhtiyaçlar & Zihinsel Dayanıklılık \\
\hline Temel Psikolojik İhtiyaçlar & 1 & \\
& 264 & \\
\hline &, $324^{* *}$ & \\
Zihinsel Dayanıklılık &, 000 & 264 \\
& 264 &
\end{tabular}

Temel psikolojik ihtiyaçlar ile zihinsel dayanıklılık ( $\mathrm{r}=.324, \mathrm{p}<.000)$ arasında pozitif yönde orta düzeye yakın bir ilişki tespit edilmiştir. Çok güçlü olmamakla birlikte temel psikolojik ihtiyaçların zihinsel dayanıklılığı olumlu yönde etkilediği söylenebilir. 


\section{TARTIŞMA VE SONUÇ}

$\mathrm{Bu}$ çalışmada doğa sporu yapan bireylerin temel psikolojik ihtiyaçlarının zihinsel dayanıklılığına olan etkisi incelenmiştir. Özellikle zihinsel dayanıklılığın doğa sporlarında performansa çok etki edecek bir unsur olduğu düşünülmüştür.

Cinsiyet değişkenine göre (Tablo 1) zihinsel dayanıklılıkta güven alt boyutunda erkekler lehine sonuçlar elde edilmiştir. Temel psikolojik ihtiyaçlarda anlamlı bir sonuç elde edilmemiştir. Genel olarak bakıldığında ortalamaların düşük olduğu görülmüştür. Doğa sporlarında, erkekler zihinsel olarak kadınlardan daha dayanıklıdır. Nicholls, Polman, Levy, ve Nicholls ve ark., (2009) sporcular üzerinde yapmış olduğu çalışmalarında, zihinsel dayanıklılık düzeyleri bakımından erkeklerin lehine olan istatistiksel bir farklılık tespit etmişlerdir. Findlay ve Bowker'ın (2009) çalışma sonuçları da cinsiyet değişkenine göre erkek futbolcuların lehine bir farklılık olduğunu aktarmıştır. Her iki çalışma da cinsiyet değişkeni açısından bulgularımızla paralellik gösteren bir sonuç elde etmiştir. Masum (2014) tarafından yapılan bir başka çalışmada da cinsiyet ile zihinsel dayanıklılık arasında anlamlı fark görüldüğü belirtilmekte ve erkek sporcuların kadın sporculara göre zihinsel dayanıklılığın ortalama puanlarının daha yüksek olduğunu tespit etmiştir.

Tablo 2 de yaşa göre sonuçlar ele alınmıştır. Özerklik alt boyutunda, 32-36 yaş aralığındaki sporcular daha fazla özerklik ihtiyacı hissetmekte oldukları görülmüştür. Sporcuların zihinsel dayanıklılık düzeylerinin yaş değişkenine göre incelendiği bir araştırmada Connaughton ve ark., (2008) spor yaşı yüksek olanların zihinsel dayanıklılık düzeyleri yüksek olmasının sebebi olarak sporcuların deneyimle birlikte kendine olan güvenlerinin gelişmesi olarak ifade etmiştir. Yine Nicholls, Levy, Polman ve Crust (2011), yapmış oldukları çalışmada zihinsel dayanıklılık ile öz yeterlik arasında pozitif yönlü ilişki olduğunu da belirtmiştir. Crust, Earle, Perry, Earle, Clough ve Clough (2014) araştırma bulgularımızı destekler nitelikte bulgular elde etmiştir. Çalışmada yaşın, zihinsel dayanıklılığın belirlenmesinde etkin bir faktör olduğu belirtilmektedir. Yaşın deneyimle olan ilişkisi olduğu düşünülmüştür. Sporcuların yaşamış oldukları deneyim yaşla birlikte artmakta ve bu durumda zihinsel olarak dayanıklılıklarını etkilemiş olabilir.

Araştırmada yapılan doğa sporu türüne bakıldığında (tablo 3), zihinsel dayanıklılık alt boyutlarından binicilik sporu yapanların daha fazla kontrolü olduğunu bunun yanı sıra dağcılık sporu yapanların kontrollerinin daha zayıf olduğu sonuçlarda görülmektedir. Bu sonuçlar araştırmamızdaki katılımcı sayıları ile bağlantılı olabilir. Gürer ve Yıldız (2015) kaya 
Gürer, B. ve Kılınç, Z. (2019). Doğa sporları yapanların temel psikolojik ihtiyaçlarının zihinsel dayanıklılığa etkisi. CBÜ Beden Ĕ̈itimi ve Spor Bilimleri Dergisi, 14 (2), 222-233.

tırmanışçıları ile yapmış olduğu çalışmasında tırmanış tekniğinin önemli olduğunu, tırmanışçıların becerileri kaybetmemesi ve dayanıklılığın artması için antrenmanların aksatılmamasına dikkat çekmiştir. Araştırmamızda tırmanış sırasında tekniği korumaya çalışılma belki de zihinsel dayanıklılık alt boyutlarından olan kontrolde etki yatarmış olabilir. Gibson (1998), zihinsel dayanıklılığın içsel bir kontrol odağı ve öz yeterlilik ile ilgili olduğunu etkili bir şekilde belirtmektedir. Zihinsel olarak dayanıklı sporcular yüksek düzeyde rekabetçi, kararlı, kendi kendini motive eden, baskı yaratan durumlarda konsantrasyonu koruyabilen bireyler olma eğilimindedirler (Crust ve Clough, 2011). Binicilik sporunda sonuçların yüksek çıkmasındaki bir etken olarak at kullanılmasının yarattığı kontrollü olma hissiyatı akla gelmektedir. Aynı düşünde dağ bisikleti içinde geçerlidir. Doğa spor yapılırken yardımcı alet ve hayvanların kullanılması daha kontrollü olmayı gerektirebilir. Belki de bir kaza sonucunda yaratacağı hasarın daha çok olacağı ve bu sebeple daha kontrollü olunması gerektiği düşünülmüştür. Gürer (2015) araştırmasında, dağcılık sporu etkinliklerinde sıkça karşı karşıya kalınan tehlikelerin var olduğuna yer vermiştir. Buna göre bisiklet ve at kaza tehlikesinden dolayı risk oluşturmakta ve doğa sporları sırasında daha kontrollü olunması sağlamaktadır.

Deneyime göre ise istatistiksel olarak bir fark bulunamamıştır (Tablo 4). Araştırmamıza katılan sporcuların deneyiminin az olduğu görülmüştür. Deneyim doğa sporlarında önemli bir rol oynayabilir. Özellikle kritik durumlarda önemli kararlar alınmasında etkili bir unsur olduğu akla gelmektedir. İstatistiksel olarak bir fark olmasa da ortalamaların hem temel psikolojik ihtiyaçlarda hem de zihinsel dayanıklılıkta iyi olduğu gözükmektedir. Gürer (2015) in dağcılar üzerine yapmış olduğu araştırmasında deneyimin problem çözme becerisi üzerinde belirgin etkisinin olmasıdır. Sportif bir başarıyı zihinsel güç, motivasyon gibi psikolojik unsurlar etkilemektedir (Mahoney, Gucciardi, Mallett ve Ntoumanis, 2014). Bu çalışmalar zihinsel olarak dayanıklı olmanın önemi ortaya koymaktadır. Benzer bir şekilde ise temel psikolojik ihtiyaçları da desteklemektedir. Psikolojik performans doğa sporlarında önemlidir. Psikolojik yeterlilik bir kişisel özelliktir ve doğa sporcusunun performansını yükseltmesinde önemli bir etkiye sahiptir. Doğa sporlarında, yaş ve deneyim arttıkça psikolojik performans da yükselmektedir (Gürer, Bektaş ve Kural, 2018).

Tablo 5'te sporcuların temel psikolojik ihtiyaçlar ve zihinsel ilişkisi verilmiştir. Çok güçlü olmamakla birlikte $(r=.324, \mathrm{p}<.000)$ temel psikolojik ihtiyaçların zihinsel dayanıklılığ olumlu yönde etkilediği görülmektedir. Farklı nedenlerle kaya tırmanışı, dağcılık ve doğa yürüyüşü yapan bireyler fizyolojik ve psikolojik yararlar elde etmektedirler. İnsanların bu tür sporlara katılımının arttırılması bireysel yararlarla fizyolojik ve psikolojik bağlamda sağlıklı 
Gürer, B. ve Kılınç, Z. (2019). Doğa sporları yapanların temel psikolojik ihtiyaçlarının zihinsel dayanıklılığa etkisi. CBÜ Beden Eğitimi ve Spor Bilimleri Dergisi, 14 (2), 222-233.

bireylerin olmasını sağlamasının yanında sağlıklı bir toplum oluşmasına da katkısı olacaktır (Kaplan ve Ardahan, 2013). Bu sonuca göre temel psikolojik ihtiyaçlar geliştikçe zihinsel dayanıklılığında geliştiği söylenebilir.

Sonuç olarak, doğa sporcularında temel psikolojik ihtiyaçlardan ziyade zihinsel dayanıklılık önemlidir. Doğa sporları bireylerin temel psikolojik özelliklerini karşılamaktadır. Zihinsel dayanıklılık ve temel psikolojik özellikler birbirleri ile olumlu bir etkileşim halindedir. Doğa sporu deneyimi tüm bu özelliklere katkı sunmaktadır. Kısaca söylemek gerekirse doğa sporları psikolojik ve zihinsel gelişim için önemlidir. Deneyim sayısının artırılarak bu tip özelliklerin geliştirilebileceği düşünülmektedir. Doğa sporları riskli bir etkinlik alanı olması sebebi ile özellikle psikolojik ve zihinsel olarak güçlü karakterlere ihtiyaç duymaktadır. Sporcuların beceri ve kabiliyet seviyelerine göre deneyimlerini arttırması önerilmektedir.

\section{KAYNAKLAR}

Altıntaş, A. \& Bayar Koruç, P. (2016). Sporda zihinsel dayanıklılık envanteri’nin psikometrik özelliklerinin incelenmesi. Hacettepe Journal of Sport Sciences, 27(4), 162-171.

Burke, S.M., Orlick, T (2003). Mental strategies of elite high altitude climbers: Overcoming adversity on mount everest, Journal of Human Performance in Extreme Environments, 7(2), 15-22.

Cherry, H. L. (2005). Psychometric analysis of an inventory assessing mental toughness. University of Tennessee, Masters Theses.

Connaughton, D., Wadey, R., Hanton, S., \& Jones, G. (2008). The development and maintenance of mental toughness: Perceptions of elite performers. Journal of sports sciences, 26(1), 83-95.

Crust, L., \& Clough, P. (2011). Developing mental toughness: from research to practice. Journal of Sport Psychology in Action, 2(1), 21-32.

Crust, L., Earle, K., Perry, J., Earle, F., Clough, A., \& Clough, P. J. (2014). Mental toughness in higher education: Relationships with achievement and progression in first-year university sports students. Personality and Individual Differences, 69, $87-91$.

Deci, E. L. \& Ryan, R. M. (2000). The 'what' and 'why' of goal pursuits: Human need sand the self-determination of behavior. Psychological Inquiry, 11(4), 227-268.

Deci, E. L., Ryan, R. M., Gagné, M., Leone, D. R., Usunov, J. ve Kornazheva, B. P. (2001). Need satisfaction, motivation, and well-being in the work organizations of a former Eastern Bloc country. Personality and Social Psychology Bulletin, 27(8), 930-942.

Findlay, L. C., \& Bowker, A. (2009). The link between competitive sport participation and self-concept in early adolescence: A consideration of gender and sport orientation. Journal of Youth and Adolescence, 38(1), 29-40.

Gibson, A. (1998). Mental Toughness. New York: Vantage Press.

Glasser, W. (1999). Kişisel Özgürlüğ̈̈n Psikolojisi. Çeviren: Müge İzmirli. İstanbul: Hayat Yayınları.

Godbey, G. (2009). Outdoor Recreation, Health, and Wellness. Understanding and Enhancing the Relationship. Resources for the Future. May. 1-29.

Gürer, B., \& Yıldız, M. E. (2015). Investigation of sport rock climbers' Handgrip Strength. Biology of Exercise, 11(2), 55-71. 
Gürer, B. ve Kılınç, Z. (2019). Doğa sporları yapanların temel psikolojik ihtiyaçlarının zihinsel dayanıklılığa etkisi. CBÜ Beden Eğitimi ve Spor Bilimleri Dergisi, 14 (2), 222-233.

Gürer, B. (2015). The investigation of problem solving skill of the mountaineers in terms of demographic variables. Educational Research and Reviews, 10(11), 1496-1504.

Gürer, B., Bektaş, F., \& Kural, B. (2018). Doğa sporları faaliyetlerine katılan sporcuların psikolojik performanslarının incelenmesi. Spor ve Performans Araştırmaları Dergisi, 9(2), 74-85.

Gürer, B., Karababa, E. M., \& Canl1, E. (2019). The Effect of Mental Toughness of Individuals Doing Outdoor Sports on their Decision-Making Skills. Turkish Journal of Sport and Exercise, 21(1), 144-154.

Kaplan A., Ardahan F. (2013). Doğa sporları yapan bireylerin profilleri, doğa sporu yapma nedenleri ve elde ettikleri faydalar: Antalya örneği . Giresun Üniversitesi, Sosyal Bilimler Enstitüsü, Karadeniz Sosyal Bilimler Dergisi, 8, 93-114.

Karakaş, G., Kaya, H. B., \& Yılmaz, A. (2018). Doğa kampı eğitiminin deneyimsel sonuçları. Eğitim ve Bilim, 43(196), 281300.

Kelly J.R. (1990). Leisure. Englewood, Cliffs, New Jersey: Prentice-Hall.

Kesici, Ş., Üre Ö., Bozgeyikli, H. ve Sünbül, A. M. (2003). Temel psikolojik ihtiyaçlar ölçeğinin geçerlik ve güvenirliği. VII. Ulusal PDR Kongresi Bildiri Özetleri Kitabi, Malatya, s.85.

Kuzgun, Y. (2000). Meslek Danışmanlı̆̆l, Uygulamalar, Kuramlar. Ankara: Nobel Yayınları.

Loehr, J. (1982). Mental toughness trainingfor sports. New York: The Stephen Greene Press.

Mahoney, J.W., Gucciardi, D.F., Mallett, C.J., Ntoumanis, N. (2014). Adolescent performers' perspectives on mental toughness and its development: The Utility of the Bioecological Model. Sport Psychologist, 28(3), 233-244.

Masum, R. (2014). A mixed method analysis of mental toughness in elite and sub-elite male and female tennis players in Pakistan. Advances in Social Sciences Research Journal, 1,110-122.

Morgan, C. (1984). Psikolojiye giriş. (Çev. Hüsnü Arıcı ve Ark.) Ankara: Hacettepe Üniversitesi, Psikoloji Bölümü Yayınları.

Neuman, J. (2004). Education and learning through outdoor activities. "Games and problem solving activities, outdoor exercises and rope courses for youth programmes." Prague: DUHA.

Nicholls, A. R., Polman, R. C., Levy, A. R., \& Backhouse, S. H. (2009). Mental toughness in sport: Achievement level, gender, age, experience, and sport type differences. Personality and Individual Differences, 47(1), 73-75.

Nicholls, A. R., Levy, A. R., Polman, R. C., \& Crust, L. (2011). Mental toughness, coping self-efficacy, and coping effectiveness among athletes. International Journal of Sport Psychology, 42(6), 513-524.

Rapport, Z. (2007). Using choice theory to assess the needs of persons who have a disability and sexual/intimacy/romantic 1ssues. International Journal of Reality Therapy, 27 (1), 22-25.

Sheard, M., Golby, J., \& Van, Wersch, A. (2009). Progress towards construct validation of the Sports Mental Toughness Questionnaire (SMTQ). European Journal of Psychological Assessment, 25, 186-193.

Sheard, M. (2013). Mental Toughness: The Mindset Behind Sporting Achievement. Second Edition, Hove, East Sussex: Routledge. 